\title{
Best Evidence Rehabilitation for Chronic Pain Part 3: Low Back Pain
}

\author{
Anneleen Malfliet 1,2,3,4,5,*(D), Kelly Ickmans 1,2,3,4 (D), Eva Huysmans 1,2,3,4,6, \\ Iris Coppieters 2,3,4,5, Ward Willaert 2,3,5, Wouter Van Bogaert 2,3, Emma Rheel 2,3,7, \\ Thomas Bilterys ${ }^{2,3}{ }^{(D)}$, Paul Van Wilgen $2,3,8$ and Jo Nijs ${ }^{2,3,4, *}$ \\ 1 Research Foundation-Flanders (FWO), 1090 Brussels, Belgium \\ 2 Department of Physiotherapy, Human Physiology and Anatomy (KIMA), Faculty of Physical Education \& \\ Physiotherapy, Vrije Universiteit Brussel, 1090 Brussels, Belgium \\ 3 Pain in Motion International Research Group, 1090 Brussels, Belgium \\ 4 Department of Physical Medicine and Physiotherapy, University Hospital Brussels, Laarbeeklaan 101, \\ 1090 Brussels, Belgium \\ 5 Department of Rehabilitation Sciences and Physiotherapy, Faculty of Medicine and Health Sciences, \\ Ghent University, 9000 Gent, Belgium \\ 6 Department of Public Health (GEWE), Faculty of Medicine and Pharmacy, Vrije Universiteit Brussel, \\ 1090 Brussels, Belgium \\ 7 Department of Experimental-Clinical and Health Psychology, Ghent University, 9000 Ghent, Belgium \\ 8 Transcare, Transdisciplinary Pain Management Centre, 9728 EE Groningen, The Netherlands \\ * Correspondence: anneleen.malfliet@vub.be (A.M.); Jo.Nijs@vub.be (J.N.)
}

Received: 6 June 2019; Accepted: 16 July 2019; Published: 19 July 2019

\begin{abstract}
Chronic Low Back Pain (CLBP) is a major and highly prevalent health problem. Given the high number of papers available, clinicians might be overwhelmed by the evidence on CLBP management. Taking into account the scale and costs of CLBP, it is imperative that healthcare professionals have access to up-to-date, evidence-based information to assist them in treatment decision-making. Therefore, this paper provides a state-of-the-art overview of the best evidence non-invasive rehabilitation for CLBP. Taking together up-to-date evidence from systematic reviews, meta-analysis and available treatment guidelines, most physically inactive therapies should not be considered for CLBP management, except for pain neuroscience education and spinal manipulative therapy if combined with exercise therapy, with or without psychological therapy. Regarding active therapy, back schools, sensory discrimination training, proprioceptive exercises, and sling exercises should not be considered due to low-quality and/or conflicting evidence. Exercise interventions on the other hand are recommended, but while all exercise modalities appear effective compared to minimal/passive/conservative/no intervention, there is no evidence that some specific types of exercises are superior to others. Therefore, we recommend choosing exercises in line with the patient's preferences and abilities. When exercise interventions are combined with a psychological component, effects are better and maintain longer over time.
\end{abstract}

Keywords: pain neuroscience; musculoskeletal pain; rehabilitation medicine; physiotherapy; lifestyle

\section{Introduction}

Chronic Low Back Pain (CLBP) is a major health problem worldwide and prevalence numbers have increased substantially in the past decades [1]. A global systematic review reports a linear correlation between age and CLBP prevalence, more specifically, individuals aged between 20 and 59 have a CLBP prevalence of $19.6 \%$, while the prevalence in older people is $25.4 \%$ [2]. Besides pain, disability is reported very frequently. CLBP is a major contributor to the global disability burden, 
and continues to be the leading cause of years lived with disability [3,4]. About half of the people who experience LBP will seek care [5]. Given the high prevalence numbers of CLBP [2], this relates to excessive direct and indirect health care costs as well as a major social and economic impact [6,7].

Current guidelines recommend non-pharmacological and non-invasive management, including the advice to stay active, the use of patient education and exercise therapy [8]. Yet, given the high number of treatment guidelines, systematic reviews and randomized controlled trials on CLBP management, clinicians might be overwhelmed by the evidence available. Taking into account the scale and costs of the CLBP problem, it is imperative that healthcare professionals involved in CLBP management should have access to up-to-date, evidence-based information to assist them in treatment decision-making. Therefore, this paper aims to endorse consistent best practice, to reduce unwarranted variation and to diminish the use of low-value interventions in CLBP care.

Here, a state-of-the-art overview of the best evidence non-invasive rehabilitation for people having CLBP is provided. The best evidence non-invasive rehabilitation is reviewed in a way that clinicians can integrate the evidence into their daily clinical routine. In addition, the state-of-the-art overview also serves clinical researchers to build upon the best evidence for designing future trials and implementation studies, and to develop new innovative studies.

\section{State of the Art}

To cover the best evidence non-invasive rehabilitation, this section relies on systematic reviews and meta-analyses primarily. A non-systematic search of the literature was performed in PubMed, Web of Science and Google Scholar using the following search terms: rehabilitation, chronic low back pain, chronic back pain, chronic lumbar pain, chronic lower back pain. When possible, we used 'systematic review', and 'meta-analysis' filters. Additionally, information from several international clinical guidelines was retrieved and discussed.

Given the strong empirical support indicating that pain severity alone is not a robust predictor of function and improvement, we will focus both on pain and function as outcomes for chronic low back pain management $[9,10]$.

\subsection{Evidence from Systematic Reviews, and Meta-Analyses}

A non-systematic search for evidence on non-invasive rehabilitation modalities for CLBP increases the understanding that CLBP is not only a common health problem but is also highly investigated. Unfortunately, many systematic reviews focus on LBP in general, and include both (sub)acute and chronic LBP. When the results of both populations were merged together in a review and specific conclusions for CLBP could not be identified, these papers were excluded from this overview. An outline of the available systematic reviews and meta-analyses that focused solely on CLBP, or in which CLBP results could be isolated, can be found in Table 1. If more than one systematic review was found regarding a specific topic, priority was given to including a meta-analysis (if available) and/or the most recent paper available.

The overview of evidence available from systematic review and meta-analyses is presented using the subdivision based on physically 'active' and 'inactive' interventions. Yet, this subdivision is chosen for practical reasons, and relies on whether an intervention requires the patient to be physically active or not. Therefore, pain neuroscience education will be discussed as part of the physically inactive interventions. Yet, we would like to stress that pain neuroscience education requires mental and cognitive activity of the patient given the required interaction between patient and therapist. 
Table 1. Best evidence table for non-invasive rehabilitation in people with chronic low back pain: evidence from systematic reviews and meta-analyses.

\begin{tabular}{|c|c|c|c|c|c|c|}
\hline Author, Year & LoE & $\begin{array}{l}\text { Intervention and } \\
\text { Sample }\end{array}$ & Main Outcomes and Results & $\begin{array}{l}\text { Mono-/Multi-/ } \\
\text { Transdisciplinary } \\
\text { [Involved } \\
\text { Rehabilitation } \\
\text { Professions] }\end{array}$ & Remarks & $\begin{array}{l}\text { Recommended for Clinical } \\
\text { Practice? }\end{array}$ \\
\hline \multicolumn{7}{|c|}{ Physically inactive interventions } \\
\hline Noori, 2019 [11] & $1 \mathrm{~A}$ & $\begin{array}{l}\text { Therapeutic ultrasound } \\
(n=333)\end{array}$ & $\begin{array}{l}3 \text { studies: } \downarrow \text { pain after ultrasound compared to } \\
\text { placebo or exercise } \\
3 \text { studies: no effect }\end{array}$ & $\begin{array}{l}\text { Not stated } \\
{[\text { Not stated] }}\end{array}$ & $\begin{array}{l}\text { Small samples, most } \\
\text { studies lack follow-up } \\
\text { period. } \\
\text { No meta-analyses. }\end{array}$ & $\begin{array}{l}\text { Lack of strong evidence for the use } \\
\text { of ultrasound (LoC 1) }\end{array}$ \\
\hline Li, 2019 [12] & $1 \mathrm{~A}$ & $\begin{array}{l}\text { Kinesiotape }(n=627) \\
\text { Meta-analysis }\end{array}$ & $\begin{array}{l}\text { Pain intensity: No significant effect } \\
\text { Disability: Significant } \downarrow \text { in Oswestry Disability } \\
\text { Index, but not in Roland Morris Disability } \\
\text { Questionnaire }\end{array}$ & $\begin{array}{l}\text { Monodisciplinary } \\
\text { [Physiotherapist] }\end{array}$ & / & $\begin{array}{l}\text { Lack of evidence for the use of } \\
\text { kinesiotape (LoC 1) }\end{array}$ \\
\hline Wood, 2019 [13] & $1 \mathrm{~A}$ & $\begin{array}{l}\text { Pain Neuroscience } \\
\text { Education }(\mathrm{PNE})(n=615) \\
\text { Meta-analysis }\end{array}$ & $\begin{array}{l}\text { PNE alone: no significant change in pain, but } \\
\text { significant } \downarrow \text { in disability and kinesiophobia at } \\
\text { short term compared to an alternative intervention. } \\
\text { PNE combined with other PT interventions: } \\
\text { significant } \downarrow \text { in pain at short-term. }\end{array}$ & $\begin{array}{l}\text { Monodisciplinary } \\
\text { [Physiotherapist or } \\
\text { general practitioners] }\end{array}$ & $\begin{array}{l}\text { Heterogeneity in } \\
\text { outcome measures. }\end{array}$ & $\begin{array}{l}\text { Moderate quality evidence to use } \\
\text { pain neuroscience education as } \\
\text { adjunct to usual physiotherapy } \\
\text { (LoC 1) }\end{array}$ \\
\hline Resende, 2018 [14] & $1 \mathrm{~A}$ & $\begin{array}{l}\text { Transcutaneous electrical } \\
\text { nerve stimulation (TENS) } \\
(n=575) \\
\text { Meta-analysis }\end{array}$ & $\begin{array}{l}\text { Pain: Significant reduction during therapy, but not } \\
\text { immediately after therapy or at } 1 \text { or } 3 \text { mo follow-up. } \\
\text { Disability: No effect during, or after therapy. }\end{array}$ & $\begin{array}{l}\text { Not stated } \\
\text { [Not stated] }\end{array}$ & $\begin{array}{l}\text { Similar conclusion in } \\
\text { other meta-analysis on } \\
\text { effects of TENS on } \\
\text { chronic back pain }(\mathrm{Wu} \text {, } \\
\text { 2018) [15] }\end{array}$ & $\begin{array}{l}\text { Not recommended to use for CLBP } \\
\text { (LoC 1) }\end{array}$ \\
\hline Furlan, 2015 [16] & $1 \mathrm{~A}$ & $\begin{array}{l}\text { Massage }(n=2548) \\
\text { Meta-analysis }\end{array}$ & $\begin{array}{l}\text { Compared to inactive control: Massage may be } \\
\text { more effective for pain and disability at short term. } \\
\text { Conclusions at long term are unclear. } \\
\text { Compared to active control: Results are unclear, } \\
\text { no conclusions can be made at short-and long-term } \\
\text { follow-up. }\end{array}$ & $\begin{array}{l}\text { Not stated } \\
{[\text { Not stated] }}\end{array}$ & $\begin{array}{l}\text { Subacute and CLBP } \\
\text { results are presented as } \\
\text { one group. } \\
\text { Very low quality of } \\
\text { evidence. }\end{array}$ & $\begin{array}{l}\text { Massage is not recommended to } \\
\text { treat CLBP (LoC 1) }\end{array}$ \\
\hline Orrock, 2013 [17] & $1 \mathrm{~A}$ & $\begin{array}{l}\text { Osteopathic intervention } \\
(n=330)\end{array}$ & $\begin{array}{l}\text { Similar effect of osteopathic intervention when } \\
\text { compared to sham intervention or exercise and PT. }\end{array}$ & $\begin{array}{l}\text { Monodisciplinary } \\
\text { [Osteopath] }\end{array}$ & $\begin{array}{l}\text { Only two studies } \\
\text { available. } \\
\text { No meta-analysis. }\end{array}$ & $\begin{array}{l}\text { Not recommended due to lack of } \\
\text { evidence (LoC 1) }\end{array}$ \\
\hline
\end{tabular}


Table 1. Cont.

\begin{tabular}{|c|c|c|c|c|c|c|}
\hline Author, Year & LoE & $\begin{array}{l}\text { Intervention and } \\
\text { Sample }\end{array}$ & Main Outcomes and Results & $\begin{array}{l}\text { Mono-/Multi-/ } \\
\text { Transdisciplinary } \\
\text { [Involved } \\
\text { Rehabilitation } \\
\text { Professions] } \\
\end{array}$ & Remarks & $\begin{array}{l}\text { Recommended for Clinical } \\
\text { Practice? }\end{array}$ \\
\hline $\begin{array}{l}\text { Rubinstein, } 2019 \\
\text { [18] }\end{array}$ & $1 \mathrm{~A}$ & $\begin{array}{l}\text { Spinal manipulative } \\
\text { therapy }(n=9211) \\
\text { Meta-analysis }\end{array}$ & $\begin{array}{l}\text { Pain: Moderate evidence that spinal manipulative } \\
\text { therapy provides statistically better results than } \\
\text { other interventions (exercise, PT, back school, } \\
\text { medical care) at } 6 \mathrm{mo} \text {, but not at } 1 \text { and } 12 \mathrm{mo} \\
\text { follow-up. } \\
\text { Function: Moderate quality evidence that spinal } \\
\text { manipulative therapy provides a small, statistically } \\
\text { better result than other interventions at } 1 \mathrm{mo} \text {, but } \\
\text { not at } 6 \text { or } 12 \mathrm{mo} \text { follow-up. }\end{array}$ & $\begin{array}{l}\text { Monodisciplinary } \\
\text { [Physiotherapist, } \\
\text { chiropractor, manual } \\
\text { therapist, osteopath] }\end{array}$ & $\begin{array}{l}\text { Many studies with high } \\
\text { risk of bias. }\end{array}$ & $\begin{array}{l}\text { Possible adjunctive therapy. } \\
\text { Produces similar effects to } \\
\text { recommended therapies. Possibility } \\
\text { of adverse events. (LoC 1) }\end{array}$ \\
\hline \multicolumn{7}{|c|}{ Physically active interventions } \\
\hline $\begin{array}{l}\text { Hajihasani, } 2019 \\
\text { [19] }\end{array}$ & $1 \mathrm{~A}$ & $\begin{array}{l}\text { Adding Cognitive } \\
\text { Behavioral Therapy (CBT) } \\
\text { to PT }(n=965)\end{array}$ & $\begin{array}{l}\text { Compared to PT alone: Pain: mixed results, } \\
\text { significant } \downarrow \text { in } 5 \text { out of } 10 \text { studies; Disability: mixed } \\
\text { results, significant } \downarrow \text { in } 4 \text { out of } 7 \text { studies; } \\
\text { Quality of Life: mixed results, significant } \downarrow \text { in } 2 \text { out } \\
\text { of } 5 \text { studies; Depression: mixed results, } 2 \text { studies } \\
\text { show no changes, while one study shows } \\
\text { exacerbation of depressive symptoms after } \\
\text { adding CBT. }\end{array}$ & $\begin{array}{l}\text { Mono- or } \\
\text { multidisciplinary } \\
\text { [Psychologist and } \\
\text { physiotherapist] }\end{array}$ & No meta-analysis. & $\begin{array}{l}\text { Mixed results, no clear indication for } \\
\text { adding CBT to PT (LoC 1) }\end{array}$ \\
\hline Zhang, 2019 [20] & $1 \mathrm{~A}$ & $\begin{array}{l}\text { Group-based } \\
\text { physiotherapist-led } \\
\text { behavioral psychological } \\
\text { interventions }(n=1927) \\
\text { Meta-analysis }\end{array}$ & $\begin{array}{l}\text { Compared to waitlist or usual care: Significant } \\
\text { pain reduction at short-, intermediate, and } \\
\text { long-term follow-up. } \\
\text { Compared to active treatment: No difference } \\
\text { between groups at short- or intermediate, but } \\
\text { significant lower pain after behavioral therapy at } \\
\text { long-term follow-up. }\end{array}$ & $\begin{array}{l}\text { Monodisciplinary } \\
\text { [Physiotherapist] }\end{array}$ & $\begin{array}{l}\text { Heterogeneity in } \\
\text { methods. }\end{array}$ & $\begin{array}{l}\text { Yes, while there is no difference with } \\
\text { active treatments at short and } \\
\text { intermediate follow-up, behavioral } \\
\text { treatments appear more effective at } \\
\text { long-term follow-up. } \\
\text { There are indications that the } \\
\text { addition of behavioral components } \\
\text { can reduce sick leave. }\end{array}$ \\
\hline Vanti, 2019 [21] & $1 \mathrm{~A}$ & $\begin{array}{l}\text { Walking interventions } \\
(n=510) \\
\text { Meta-analysis }\end{array}$ & $\begin{array}{l}\text { Pain, disability, quality of life and fear-avoidance } \\
\text { improve equally by walking or exercise. }\end{array}$ & $\begin{array}{l}\text { Not stated } \\
\text { [Physiotherapist] }\end{array}$ & $\begin{array}{l}\text { Same conclusion in } \\
\text { similar meta-analysis by } \\
\text { Sitthiporn-vorakul, } 2018 \\
\text { [22] }\end{array}$ & $\begin{array}{l}\text { Walking is not more effective for } \\
\text { reducing pain and disability } \\
\text { compared to exercise or education, } \\
\text { but can be used as a low-budget and } \\
\text { easy accessible alternative (LoC 1) }\end{array}$ \\
\hline
\end{tabular}


Table 1. Cont.

\begin{tabular}{|c|c|c|c|c|c|c|}
\hline Author, Year & LoE & $\begin{array}{l}\text { Intervention and } \\
\text { Sample }\end{array}$ & Main Outcomes and Results & $\begin{array}{l}\text { Mono-/Multi-/ } \\
\text { Transdisciplinary } \\
\text { [Involved } \\
\text { Rehabilitation } \\
\text { Professions] } \\
\end{array}$ & Remarks & $\begin{array}{c}\text { Recommended for Clinical } \\
\text { Practice? }\end{array}$ \\
\hline Van Erp, 2018 [23] & $1 \mathrm{~A}$ & $\begin{array}{l}\text { Primary Care } \\
\text { Interventions Using a } \\
\text { Biopsychosocial } \\
\text { Approach }(n=1426)\end{array}$ & $\begin{array}{l}\text { Compared to education/advice: } \\
\text { Functional disability } \downarrow \text { at short, mid and long term; } \\
\text { Pain } \downarrow \text { at short, mid and long term; Quality of life: } \\
\text { No differences } \\
\text { Compared to physical activity therapy: } \\
\text { Functional disability: No differences; Pain: mixed } \\
\text { results, } 2 \text { out of } 4 \text { studies report significant } \downarrow \text { in pain } \\
\text { in biopsychosocial approach }\end{array}$ & $\begin{array}{l}\text { Mono- or } \\
\text { multidisciplinary } \\
\text { [Physiotherapist, } \\
\text { combined with } \\
\text { nurses, psychologist, } \\
\text { or occupational } \\
\text { therapist] }\end{array}$ & $\begin{array}{l}\text { Heterogeneity in study } \\
\text { and treatment designs. } \\
\text { No meta-analysis. }\end{array}$ & $\begin{array}{l}\text { Use of bio-psychosocial } \\
\text { interventions in primary care is } \\
\text { beneficial over education and advice } \\
\text { (LoC 1) }\end{array}$ \\
\hline Wewege, 2018 [24] & $1 \mathrm{~A}$ & $\begin{array}{l}\text { Aerobic and resistance } \\
\text { exercise interventions } \\
(n=322) \\
\text { Meta-analysis }\end{array}$ & $\begin{array}{l}\text { Pooled results of aerobic and resistance training: } \\
\text { Small significant improvement in pain and a trend } \\
\text { towards significance for decreased disability and } \\
\text { improved mental health. No differences were } \\
\text { found for physical health (SF36). }\end{array}$ & $\begin{array}{l}\text { Monodisciplinary } \\
\text { [Physiotherapist or } \\
\text { exercise therapist] }\end{array}$ & / & $\begin{array}{l}\text { Moderate quality evidence for the } \\
\text { use of aerobic and resistance training } \\
\text { (LoC 1) }\end{array}$ \\
\hline $\begin{array}{l}\text { Luomajoki, } 2018 \\
\text { [25] }\end{array}$ & $1 \mathrm{~A}$ & $\begin{array}{l}\text { Movement control } \\
\text { exercise therapy }(n=781) \\
\text { Meta-analysis }\end{array}$ & $\begin{array}{l}\text { In global group: Short-term } \downarrow \text { in disability, but not } \\
\text { in pain compared to active control treatment. No } \\
\text { long-term effects. } \\
\text { In subgroup with movement control impairment: } \\
\text { Short- and long-term } \downarrow \text { in pain and disability. }\end{array}$ & $\begin{array}{l}\text { Monodisciplinary } \\
\text { [Physiotherapist] }\end{array}$ & $\begin{array}{l}\text { Small sample sized and } \\
\text { heterogeneity of } \\
\text { included studies. }\end{array}$ & $\begin{array}{l}\text { Very low to moderate quality of } \\
\text { evidence to use movement control } \\
\text { exercises in CLBP AND movement } \\
\text { control impairment (LoC 1) }\end{array}$ \\
\hline Parreira, 2017 [26] & $1 \mathrm{~A}$ & $\begin{array}{l}\text { Back School }(n=4105) \\
\text { Meta-analysis }\end{array}$ & $\begin{array}{l}\text { Pain: Low quality of evidence for reduction at short } \\
\text { term, but not at intermediate or long-term } \\
\text { follow-up compared to no treatment. } \\
\text { Disability: Low quality of evidence that back } \\
\text { schools are not effective at intermediate or } \\
\text { long-term follow-up compared to no treatment. }\end{array}$ & $\begin{array}{l}\text { Monodisciplinary } \\
\text { [Physiotherapist or } \\
\text { medical specialist] }\end{array}$ & Low quality of evidence & $\begin{array}{l}\text { Because of low quality of evidence, } \\
\text { back schools are not recommended } \\
\text { for CLBP (LoC 1) }\end{array}$ \\
\hline
\end{tabular}


Table 1. Cont.

\begin{tabular}{|c|c|c|c|c|c|c|}
\hline Author, Year & LoE & $\begin{array}{l}\text { Intervention and } \\
\text { Sample }\end{array}$ & Main Outcomes and Results & $\begin{array}{l}\text { Mono-/Multi-/ } \\
\text { Transdisciplinary } \\
\text { [Involved } \\
\text { Rehabilitation } \\
\text { Professions] } \\
\end{array}$ & Remarks & $\begin{array}{c}\text { Recommended for Clinical } \\
\text { Practice? }\end{array}$ \\
\hline Du, 2017 [27] & $1 \mathrm{~A}$ & $\begin{array}{l}\text { Self-management } \\
(n=2188) \\
\text { Meta-analysis }\end{array}$ & $\begin{array}{l}\text { Pain: Significant reduction using self-management } \\
\text { at immediate, short-term, intermediate and } \\
\text { long-term follow-up compared to a control } \\
\text { intervention. } \\
\text { Disability: Significant reduction using } \\
\text { self-management at immediate, short-term, } \\
\text { intermediate and long-term follow-up compared to } \\
\text { a control intervention. }\end{array}$ & $\begin{array}{l}\text { Mono- or } \\
\text { multidisciplinary, } \\
\text { and/or internet-based } \\
\text { [Physiotherapist, } \\
\text { psychologist, exercise } \\
\text { therapist, and/or } \\
\text { internet-based] }\end{array}$ & / & $\begin{array}{l}\text { Yes, there is moderate-quality } \\
\text { evidence that self-management has a } \\
\text { moderate effect on pain intensity, } \\
\text { and small to moderate effect on } \\
\text { disability (LoC 1) }\end{array}$ \\
\hline $\begin{array}{l}\text { López-de- } \\
\text { Uralde-Villanueva, } \\
2016 \text { [28] }\end{array}$ & $1 \mathrm{~A}$ & $\begin{array}{l}\text { Graded Activity and } \\
\text { Graded Exposure } \\
(n=1486) \\
\text { Meta-analysis }\end{array}$ & $\begin{array}{l}\text { Graded activity vs other forms of exercises: No } \\
\text { difference for disability, quality of life or pain at any } \\
\text { time-point. } \\
\text { Graded activity vs waitlist or usual care: Graded } \\
\text { activity is more effective to reduce disability, but not } \\
\text { pain at short- and long-term follow-up. } \\
\text { Graded activity vs graded exposure: Graded } \\
\text { exposure was more effective to reduce disability } \\
\text { and catastrophizing in the short term. There is no } \\
\text { difference between both regarding the effect } \\
\text { on pain. }\end{array}$ & $\begin{array}{l}\text { Not stated } \\
{[\text { Not stated] }}\end{array}$ & $\begin{array}{l}\text { Poor methodological } \\
\text { quality of many included } \\
\text { studies. } \\
\text { Possible publication bias } \\
\text { could not be assessed. }\end{array}$ & $\begin{array}{l}\text { There is limited evidence that } \\
\text { graded activity significantly reduces } \\
\text { disability in the short and long term } \\
\text { compared to a control intervention, } \\
\text { but not when compared to an active } \\
\text { control intervention. } \\
\text { There is strong evidence that graded } \\
\text { activity cannot change pain in the } \\
\text { short, intermediate, and long term } \\
\text { compared to a control intervention. } \\
\text { There are indicative findings that } \\
\text { graded exposure is better than } \\
\text { graded activity at decreasing } \\
\text { disability and catastrophizing in the } \\
\text { short term. (LoC 1) }\end{array}$ \\
\hline $\begin{array}{l}\text { Saragiotto, } 2016 \\
\text { [29] }\end{array}$ & $1 \mathrm{~A}$ & $\begin{array}{l}\text { Motor control exercise }(n \\
=2431) \\
\text { Meta-analysis }\end{array}$ & $\begin{array}{l}\text { Compared to other exercises: Small, but not } \\
\text { clinically important effect on pain and disability at } \\
\text { short term, but not at intermediate or long-term } \\
\text { follow-up. } \\
\text { Compared to manual therapy: No effect on } \\
\text { pain and disability. } \\
\text { Compared to minimal intervention: Clinical } \\
\text { important effect on pain at short- and long-term. } \\
\text { Small, but not clinically important effect on } \\
\text { disability at short- intermediate and long-term. }\end{array}$ & $\begin{array}{l}\text { Not stated } \\
\text { [Not stated] }\end{array}$ & / & $\begin{array}{l}\text { Motor control exercises are more } \\
\text { effective than a minimal } \\
\text { intervention, but is not more } \\
\text { effective than other forms of exercise } \\
\text { or manual therapy (LoC } 1 \text { ) }\end{array}$ \\
\hline
\end{tabular}


Table 1. Cont.

\begin{tabular}{|c|c|c|c|c|c|c|}
\hline Author, Year & LoE & $\begin{array}{l}\text { Intervention and } \\
\text { Sample }\end{array}$ & Main Outcomes and Results & $\begin{array}{l}\text { Mono-/Multi-/ } \\
\text { Transdisciplinary } \\
\text { [Involved } \\
\text { Rehabilitation } \\
\text { Professions] } \\
\end{array}$ & Remarks & $\begin{array}{c}\text { Recommended for Clinical } \\
\text { Practice? }\end{array}$ \\
\hline Kälin, 2016 [30] & $1 \mathrm{~A}$ & $\begin{array}{l}\text { Sensory discrimination } \\
\text { training }(n=255)\end{array}$ & $\begin{array}{l}\text { Both sensory discrimination and control treatments } \\
\text { (TENS, back school, sham treatment) led to a } \\
\text { decrease in pain and an improvement in function. }\end{array}$ & $\begin{array}{l}\text { Monodisciplinary } \\
\text { [Physiotherapist] }\end{array}$ & $\begin{array}{l}\text { Conflicting evidence, low } \\
\text { quality of included } \\
\text { studies. } \\
\text { No meta-analysis. }\end{array}$ & $\begin{array}{l}\text { Conflicting evidence, no clear } \\
\text { conclusion or recommendation } \\
\text { possible (LoC } 1 \text { ) }\end{array}$ \\
\hline Yamato, 2015 [31] & $1 \mathrm{~A}$ & $\begin{array}{l}\text { Pilates }(n=510) \\
\text { Meta-analysis }\end{array}$ & $\begin{array}{l}\text { Pain: Pilates is more effective at short and } \\
\text { intermediate term compared to minimal } \\
\text { intervention, but not compared to other exercise } \\
\text { interventions. } \\
\text { Disability: Pilates is more effective at short and } \\
\text { intermediate term compared to minimal } \\
\text { intervention, but not compared to other exercise } \\
\text { interventions. }\end{array}$ & $\begin{array}{l}\text { Monodisciplinary } \\
\text { [Pilates instructor] }\end{array}$ & $\begin{array}{l}\text { Although the review } \\
\text { focused on (sub)acute } \\
\text { and chronic LBP, but all } \\
\text { included studies dealt } \\
\text { about CLBP. }\end{array}$ & $\begin{array}{l}\text { Pilates is more effective than } \\
\text { minimal intervention (low- to } \\
\text { moderate quality of evidence), but } \\
\text { there is no evidence for the } \\
\text { superiority of Pilates to other forms } \\
\text { of exercise (LoC 1) }\end{array}$ \\
\hline Kamper, 2015 [32] & $1 \mathrm{~A}$ & $\begin{array}{l}\text { Multidisciplinary } \\
\text { biopsychosocial } \\
\text { rehabilitation }(n=6858) \\
\text { Meta-analysis }\end{array}$ & $\begin{array}{l}\text { Compared to usual care: Multidisciplinary } \\
\text { biopsychosocial rehabilitation is more effective to } \\
\text { reduce pain and disability, even at long-term. } \\
\text { Compared to physical treatment: } \\
\text { Multidisciplinary biopsychosocial rehabilitation is } \\
\text { more effective to reduce pain and disability, even at } \\
\text { long-term. }\end{array}$ & $\begin{array}{l}\text { Multidisciplinary } \\
\text { [Physical, } \\
\text { psychological, } \\
\text { educational, and/or } \\
\text { work-related } \\
\text { components delivered } \\
\text { by expert healthcare } \\
\text { providers] }\end{array}$ & $\begin{array}{l}\text { Clinical heterogeneity } \\
\text { among included studies. }\end{array}$ & $\begin{array}{l}\text { Yes, } \\
\text { multidisciplinary biopsychosocial } \\
\text { rehabilitation is more effective than } \\
\text { usual care or physical treatment } \\
\text { (LoC 1) }\end{array}$ \\
\hline Searle, 2015 [33] & $1 \mathrm{~A}$ & $\begin{array}{l}\text { Exercise interventions }(n \\
=4462) \\
\text { Meta-analysis }\end{array}$ & $\begin{array}{l}\text { General comparison: Exercise has a small but } \\
\text { significant benefit for the treatment of non-specific } \\
\text { CLBP and is more effective than conservative } \\
\text { therapies (wait list or usual activities, general } \\
\text { practitioner } \\
\text { care, electrotherapies and manipulative therapies). } \\
\text { Sub-analysis: Strength/resistance, } \\
\text { coordination/stabilization, and combined exercise is } \\
\text { more effective than conservative therapies, but not } \\
\text { cardiorespiratory exercise. }\end{array}$ & $\begin{array}{l}\text { Not stated } \\
\text { [Not stated] }\end{array}$ & $\begin{array}{l}\text { Heterogeneity in } \\
\text { application of exercise } \\
\text { interventions. }\end{array}$ & $\begin{array}{l}\text { Yes. Beneficial effect of } \\
\text { strength/resistance and } \\
\text { coordination/stabilization exercise } \\
\text { programs over other interventions } \\
\text { (LoC 1) }\end{array}$ \\
\hline
\end{tabular}


Table 1. Cont.

\begin{tabular}{|c|c|c|c|c|c|c|}
\hline Author, Year & LoE & $\begin{array}{c}\text { Intervention and } \\
\text { Sample }\end{array}$ & Main Outcomes and Results & $\begin{array}{c}\text { Mono-/Multi-/ } \\
\text { Transdisciplinary } \\
\text { [Involved } \\
\text { Rehabilitation } \\
\text { Professions] }\end{array}$ & Remarks & $\begin{array}{c}\text { Recommended for Clinical } \\
\text { Practice? }\end{array}$ \\
\hline $\begin{array}{l}\text { McCaskey, } 2014 \\
\text { [34] }\end{array}$ & $1 \mathrm{~A}$ & $\begin{array}{l}\text { Proprioceptive exercises } \\
(n=1380)\end{array}$ & $\begin{array}{l}\text { Perceptual proprioceptive training: More effective } \\
\text { for pain reduction than back school. Two studies, } \\
\text { very low quality of evidence. } \\
\text { Joint repositioning training: More effective for } \\
\text { short-term pain reduction than no intervention. No } \\
\text { difference with other exercises. Low quality of } \\
\text { evidence. } \\
\text { Multimodal proprioceptive training: More } \\
\text { effective for short-term pain reduction than no } \\
\text { intervention. No difference with other exercises. } \\
\text { Low quality of evidence. }\end{array}$ & $\begin{array}{l}\text { Monodisciplinary } \\
\text { [Physiotherapist] }\end{array}$ & $\begin{array}{l}\text { Overall low quality of } \\
\text { evidence. } \\
\text { No meta-analysis. }\end{array}$ & $\begin{array}{l}\text { No consistent benefit in adding } \\
\text { proprioceptive exercises for CLPB } \\
\text { rehabilitation (LoC } 1 \text { ) }\end{array}$ \\
\hline Yue, 2014 [35] & $1 \mathrm{~A}$ & $\begin{array}{l}\text { Sling exercise }(n=706) \\
\text { Meta-analysis }\end{array}$ & $\begin{array}{l}\text { Sling exercises are not more effective for improving } \\
\text { pain or function compared to other forms of } \\
\text { exercise. }\end{array}$ & $\begin{array}{l}\text { Not stated } \\
{[\text { Not stated] }}\end{array}$ & $\begin{array}{l}\text { Low quality of included } \\
\text { studies. }\end{array}$ & $\begin{array}{l}\text { Based on the available evidence, } \\
\text { sling exercises are not recommended } \\
\text { (LoC 1) }\end{array}$ \\
\hline $\begin{array}{l}\text { Holtzman, } 2013 \\
{[36]}\end{array}$ & $1 \mathrm{~A}$ & $\begin{array}{l}\text { Yoga }(n=851) \\
\text { Meta-analysis }\end{array}$ & $\begin{array}{l}\text { Pain and disability improved directly } \\
\text { post-treatment (moderate to large effect sizes) and } \\
\text { remained at long-term follow-up (small to medium } \\
\text { effect sizes). Effects were compared to no } \\
\text { treatment/waitlist, stretching, usual care, education } \\
\text { and exercise. }\end{array}$ & $\begin{array}{l}\text { Monodisciplinary } \\
\text { [Yoga therapist] }\end{array}$ & $\begin{array}{l}\text { Heterogeneity in yoga } \\
\text { interventions. High } \\
\text { quality of included } \\
\text { studies. }\end{array}$ & $\begin{array}{l}\text { Yes, possible adjunctive to PT } \\
\text { intervention (LoC 1) }\end{array}$ \\
\hline $\begin{array}{l}\text { Hoffman, } 2007 \\
\text { [37] }\end{array}$ & $1 \mathrm{~A}$ & $\begin{array}{l}\text { Psychological } \\
\text { interventions }(n=1747) \\
\text { Meta-analysis }\end{array}$ & $\begin{array}{l}\text { Compared to waitlist: Psychological interventions } \\
\text { are superior to reduce pain intensity and } \\
\text { health-related quality of life. } \\
\text { Compared to active control (e.g., treatment as } \\
\text { usual) intervention: Psychological interventions } \\
\text { are not superior }\end{array}$ & $\begin{array}{l}\text { Mono- or } \\
\text { multidisciplinary } \\
\text { [Not stated] }\end{array}$ & l & $\begin{array}{l}\text { Psychological interventions are more } \\
\text { effective than no intervention, but } \\
\text { not compared to active interventions } \\
\text { (LoC 1) }\end{array}$ \\
\hline
\end{tabular}

Level of Evidence (LoE): 1A: Systematic review of randomized controlled trials; 1B: Individual randomized controlled trials; 2A: Systematic review of cohort studies; $2 \mathrm{~B}$ : Individual cohort study or low quality randomized controlled trials; 3A: Systematic review of case-control studies; 3B: individual case-control study; 4: Case-series; 5: Expert opinion. Level of Conclusion (LoC): LoC 1: Research of evidence level 1A or at least 2 independent conducted studies of evidence level 1B; LoC 2: 1 research of evidence level 1B or at least 2 independent conducted studies of evidence level 2B or 3B; LoC 31 research of evidence level 2B, 3B or 4; LoC 4: Opinion of experts or Inconclusive or inconsistent results between various studies. Abbreviations: LoE = Level of Evidence; LoC = Level of Conclusion; PT= physiotherapy; CLBP = Chronic Low Back Pain. 


\subsection{Physically Inactive Interventions}

Investigated inactive techniques for CLBP include therapeutic ultrasound, kinesiotape, pain neuroscience education, transcutaneous electrical nerve stimulation, massage, osteopathic intervention, and spinal manipulative therapy (including high-velocity low-amplitude spinal manipulations as well as low-velocity low-amplitude mobilizations). Out of these therapies, only two are recommended, and only when implemented as adjunctive therapy: pain neuroscience education and spinal manipulative therapy. All other inactive interventions (i.e., therapeutic ultrasound, kinesiotape, transcutaneous electrical nerve stimulation, massage and osteopathic interventions) are not recommended for CLBP management based on available evidence.

Pain neuroscience education aims to decrease the threat value of pain by increasing the patient's knowledge about pain and by reconceptualizing pain [38]. As stand-alone intervention, this treatment modality can reduce disability and kinesiophobia short term, but is not able to change pain [13]. However, when combined with other physiotherapeutic interventions, pain neuroscience education can significantly reduce pain short term [13]. Therefore, pain neuroscience education can be considered as a first step before applying an active intervention for people with CLBP. Given that many people with CLBP display kinesiophobia (i.e., fear of movement and avoidance behavior, which is a barrier for positive treatment outcome) [39], and active interventions are recommended (see below: 'active interventions' and 'international guidelines') [40], pain neuroscience education can prime people for further treatment by adapting beliefs and expectations. We would like to emphasize that-although here discussed among physically inactive interventions-pain neuroscience education requires a certain degree of activity of the patient. Pain neuroscience education should be delivered using intense interaction between the patient and the therapist, and therefore requires mental and cognitive activity of the patient [41,42]. Additionally, pain neuroscience education appears to enhance physical activation and its effects on pain, given the evidence that combining pain neuroscience education with a (therapeutic) exercise intervention is more effective than an exercise intervention alone (large effect size for pain intensity) $[13,43]$. Manuals to implement pain neuroscience education are available in books [44,45], and tools for clinical practice can be found online [46].

Similarly, spinal manipulative therapy can be used in clinical practice for CLBP management, but only as part of a treatment package (i.e., adjunctive therapy) given the moderate quality evidence from improvements in pain and function at short-term follow-up (1 month) but not at long term (6 or 12 months follow-up) $[18,40,47,48]$. Importantly, evidence reports several possible adverse events related to spinal manipulative therapy, which should be taken into account by the clinician before using these techniques. Reported adverse events include severe back pain, acute flare-up of back pain, inability to sleep because of pain, muscle soreness and stiffness, exacerbation of symptoms, and tiredness [18]. Interestingly, a randomized controlled trial examined if the effects on pain differed between region-specific and non-region-specific spinal manipulations in people with CLBP $(n=148)$ [49]. While both groups showed a reduction in pain intensity after the manipulation, they did not find any differences between region-specific and non-region-specific techniques. This finding appears to refute any local, biomechanical mechanisms behind the effectiveness of these techniques [49]. Changes in pain in response to manipulative techniques in people with CLBP could therefore be more related to a cascade of neurophysiological responses from both the peripheral and central nervous system as well as nonspecific effects such as expectations and psychosocial factors, rather than local tissue changes [49].

As the effects of spinal manipulative techniques in CLBP might be explained by similar mechanisms contributing to the positive effects of pain neuroscience education, some researchers suggest to combine both recommended physically inactive adjunctive therapies discussed here [50,51]. Given their similar recommendation (i.e., as adjuvant therapy to active treatment modalities), discussing their simultaneous application in clinical practice becomes relevant. Because of the aim of pain neuroscience education to shift the patient's focus away from the tissues in the low back as the source of their pain, many could conclude that pain neuroscience education should be used solely within a hands-off treatment approach. 
Yet, the meta-analysis of Wood et al. (2018) includes papers that combine pain neuroscience education with other physiotherapeutic interventions such as exercise/activity and/or manual therapy [13]. Outcomes appeared to favor the combination of pain neuroscience education with movement, either passive (manual therapy) and/or active. This suggests that combining pain neuroscience education with "hands-on" approaches results in more favorable responses than pain neuroscience education alone [51]. Yet, given the statement of The American Physical Therapy Association (APTA) that warns us for the negative effects of applying physically inactive treatments (i.e., they can delay recovery and lead to poor long-term outcomes by reinforcing a passive role, promoting inactivity and disability behavior, and 'medicalizing' the patient), combining pain neuroscience education with active exercise therapy might still be preferred over any physically inactive approach.

If a clinician were to combine pain neuroscience education with "hands-on" techniques, care should be taken that all communication to the patient fits within the biopsychosocial framework of PNE. Therefore, it should be avoided to present manual techniques within a biomedical pain model, in which the therapist is deemed to "fix" a structure [52,53]. Instead, communication can focus on the desensitizing effects of "hands-on" techniques and threatening words such as "pain" can be replaced by more neutral terms like "symptoms" [52,54].

\subsection{Physically Active Interventions}

Given the listed active interventions in Table 1 and their recommendations, physically active interventions appear to have more potential to alter symptoms in CLBP than physically inactive interventions. Yet, the following four treatment modalities are not recommended due to lack of qualitative evidence and/or conflicting evidence: back schools, sensory discrimination training, proprioceptive exercises, and sling exercises $[26,30,34,35]$. Therefore, based on current evidence, these types of therapy should not be considered for CLBP management.

The other active therapies for CLBP listed in Table 1 can be subdivided in physiotherapeutic treatment modalities that include a psychological component (i.e., multimodal), and treatment modalities that focus purely on physical exercises and movements. All included exercise modalities (aerobic exercise, strength/resistance exercise, coordination/stabilization exercise, motor control, and pilates) can effectively reduce pain and disability compared to minimal, passive/conservative, or no intervention $[24,29,31,33]$. However, when compared to each other (or to other active treatments), no differences can be found between different exercise modalities [24,29,31,33]. This is at odds with evidence in healthy people, where-for example—resistance training can reduce pain sensitivity to a greater extent than aerobic exercise [55].

Taken together, the information available regarding exercise interventions in CLBP and the wide variety in duration, intensity and methods of training, we cannot recommend which groups or types of exercise interventions are most effective [24,29,31,33]. From a motivational point of view, we recommend taking the patient's preferences and abilities into account when deciding upon exercise modalities to use. Interestingly, when exercise therapy reduces pain and disability in people with CLBP, the improvements are often unrelated to an improvement in physical function [56]. Therefore, it is suggested that other exercise-induced changes like improved psychological status and cognitions (e.g., reduced anxiety, catastrophizing, and fear) influence pain and disability more than changes in physical function. This might explain the difficulties currently encountered to identify the optimal exercise modality and dosage for CLBP management [24,57]. This statement is (partly) underscored by the evidence on treatment modalities that combine exercises with a psychological component (i.e., biopsychosocial approach) [20,23,32].

Three systematic reviews (two of which included a meta-analysis) focused on the effectiveness of a biopsychosocial treatment approach $[20,23,32]$. This approach involves a physical component combined with a psychological component and/or a social/work targeted component [32]. Results of this approach compared to other active treatments are promising. For example, while there was no difference at short- and intermediate-term follow-up, behavioral psychological interventions were 
more effective to reduce pain at short-term and long-term follow-up than active treatments without a psychological component $[20,58,59]$. Interestingly, the best results were found for multidisciplinary biopsychosocial rehabilitation [32]. Importantly, the systematic review and meta-analysis investigating this rehabilitation approach does not allow to differentiate whether the positive results emanate from the multidisciplinary approach, the biopsychosocial focus, or both, as comparator studies all involved a monodisciplinary biomedical approach (e.g., electrotherapy, aerobic, stretching and strengthening exercises, traction, TENS, manual therapy, back school, surgery, etc.) [32]. Yet, both compared to monodisciplinary usual care and to monodisciplinary physical treatment, multidisciplinary biopsychosocial rehabilitation was found to be more effective to reduce pain and disability, even at long-term follow-ups [60-67]. These results indicate that a multidisciplinary biopsychosocial approach can provide CLBP patients with relevant tools to maintain positive treatment effects long term. This is underscored by evidence that the effect on work equates to a person having roughly double the odds of being at work after 12 months if they received a multidisciplinary rehabilitation program rather than a physical treatment alone [32,68-71]. Interestingly, studies focusing on the costs-effectiveness of interdisciplinary rehabilitation programs for chronic (pediatric) pain in general found significant reductions in medical costs post-treatment compared to the pretreatment phase [72-74].

Yet, a multidisciplinary approach can be time-consuming, and resource intensive. As there is currently no evidence available that directly compares a biopsychosocial approach in a monodisciplinary versus a multidisciplinary setting, future researchers should focus on the question if it is the multidisciplinary or rather biopsychosocial focus that explains these positive results. Interestingly, a large randomized controlled trial recently conducted by our group has investigated the effectiveness of a biopsychosocial approach (i.e., combining pain neuroscience education and cognition-targeted exercise therapy) delivered monodisciplinary by a physiotherapist only [75]. This approach was able to reduce pain, symptoms of central sensitization, and to improve psychophysiological measures of central sensitization, disability, pain cognitions, mental health and physical functioning (medium to large effect sizes) compared to an active control treatment. Using this example, we want to underscore that even in a monodisciplinary setting a biopsychosocial approach can be effective and should be targeted by clinicians. A treatment manual of this approach is published and can be accessed freely online (https://bit.ly/2WcA1re) [76].

The added value of a combined, biopsychosocial approach (i.e., adding psychological components to active physiotherapy treatments) is further underscored by a systematic review and meta-analysis that focused on the effectiveness of stand-alone psychological interventions for CLBP [37]. This review concluded that, compared to a waitlist, psychological interventions were superior to reduce pain intensity and improve quality of life, but showed equal results when compared to an active (i.e., exercise) control intervention [37].

Additionally, we would like to highlight the possible advantage of incorporating graded exposure techniques into the management of chronic low back pain. Graded exposure is a treatment modality that identifies feared exercises or activities, and exposes the patient to these exercises or activities in a hierarchical fashion, starting with an exercise or activity that elicits minimal amounts of fear and progressing only when this fear reduces [28]. One systematic review and meta-analysis focusses both on graded activity and graded exposure in nonspecific CLBP [28]. While graded activity can only improve disability when compared to a waitlist or usual care control group and does not show superior to other forms of exercises, there is some indicative research showing that graded exposure is more effective than graded activity to improve disability and catastrophizing short term [28]. However, currently there are no systematic reviews or meta-analyses available to allow firm conclusions on the potential of graded exposure in chronic low back pain management. Therefore, we suggest that clinicians can screen for the possible presence of feared movements and activities, and to tackle them using graded exposure techniques upon occurrence [77,78].

Last, we would like to underline a recent meta-analysis on the effectiveness of walking interventions [21]. When compared to education or other active exercises, walking improves pain, 
disability, quality of life and fear-avoidance to a similar extent. Therefore, walking interventions are not recommended as sole use, but given the low-budget and easy, accessible characteristics of walking, it can be a valuable home-based addition to other therapy modalities as it can increase physical activity, overcome activity avoidance, and minimize barriers for other types of exercise [21,22]. Walking at a low to moderate intensity imposes low risk of (musculoskeletal) injury and can improve aerobic capacity, body mass index, systolic/diastolic blood pressure, triglyceride levels, and high-density lipoprotein cholesterol levels in both healthy and sedentary individuals $[22,79,80]$. Therefore, clinicians should consider implementing walking exercises for CLBP management, when combined with other types of recommended, active treatment.

\subsection{International Guidelines}

A critical review of LBP guidelines (2017) [81] used the Appraisal of Guidelines Research and Evaluation (AGREE) instrument to assess their quality and recommends four (out of 17 available) guidelines for LBP management [40,82-84]. Two of these guidelines (NICE guidelines and Dutch physiotherapy guidelines) focused on CLBP as a specific group apart from (sub)acute LBP $[40,82]$ and will be discussed here. For the NICE guidelines, we refer to the updated version that was published in 2016. Additionally, the recommendations of two more recently published guidelines that were not yet included in the critical review will be discussed $[85,86]$. An overview of the recommendations included in these (clinical) guidelines can be found in Table 2. We will not discuss all recommendations in detail here but will rather highlight some striking features and parallels between guidelines.

Although several differences exist between the different guidelines, exercise is recommended in all of them $[40,82,85,86]$. Interestingly, all of them also recognize that none of the exercise modalities is superior to the others: health care providers can choose any type of exercise (general, aerobic, strengthening, yoga, group-based or individual, etc.), but should specifically consider the patient's preferences, needs and capabilities while choosing the exercise modality. The NICE guidelines even take it one step further and identify exercise as key treatment modality for LBP, given the recommendation to only consider manual therapy and/or psychological therapies if it is a part of a treatment package including exercise [40]. For multidisciplinary biopsychosocial rehabilitation-the intervention that shows high potential based on available systematic reviews and meta-analysis (see Table 1) - the NICE guidelines recommend considering this approach when significant psychosocial obstacles limit recovery, or when previous treatments have not been effective.

Importantly, these guidelines all agree not to recommend transcutaneous electrical nerve stimulation, interferential therapy (electrotherapy), or ultrasound for the treatment of CLBP. Other not-to-use modalities in CLBP management as identified in at least one of these guidelines are: traction, biofeedback, massage, laser therapy, taping, lumbar support, postural exercises, orthotics, and percutaneous electrical nerve stimulation. Interestingly, all modalities that are not recommended comprise physically inactive techniques, i.e., this implies lack of participation from the individual receiving the therapy intervention. This is in line with the conclusions made based on the systematic reviews (and meta-analysis) included in Table 1. The American Physical Therapy Association (APTA) even warns us of the negative effects of applying physically inactive treatments for any type of patient: these treatments can delay recovery and lead to poor long-term outcomes by reinforcing a passive role, promoting inactivity and disability behavior, and 'medicalizing' the patient [87]. Given the 'active' focus of recommended treatment modalities, this advice should also be taken into consideration when treating patients with CLBP. While physically inactive treatments (like manual therapy) appear to have potentially positive effects, they should not be used as sole treatment but rather in a multimodal approach focusing mainly on activating the patient [40]. 
Table 2. Overview of recommendations in (clinical) guidelines for chronic low back pain management.

\begin{tabular}{|c|c|c|}
\hline Guideline & & Recommendation for CLBP \\
\hline \multirow[b]{2}{*}{$\begin{array}{l}\text { Bekkering et al. Dutch } \\
\text { Physiotherapy Guidelines for } \\
\text { Low Back Pain (2003) [82] }\end{array}$} & Recommended & $\begin{array}{l}\text { - Exercise therapy (not clear which exercises are best): Strong evidence that exercise therapy is } \\
\text { equally effective compared to passive physiotherapy techniques. Strong evidence that exercise } \\
\text { therapy is more effective than standard care by the general practitioner. } \\
\text { Behavioral treatment: may be useful. Strong evidence for a moderately positive effect on pain } \\
\text { compared to no treatment, waitlist or placebo. Effectiveness compared to other treatments not clear. }\end{array}$ \\
\hline & Not recommended & $\begin{array}{ll}- & \text { Traction } \\
- & \text { Biofeedback } \\
- & \text { Massage } \\
- & \text { Transcutaneous electrical nerve stimulation } \\
- & \text { Ultrasound } \\
- & \text { Electrotherapy } \\
- & \text { Laser therapy }\end{array}$ \\
\hline \multirow[t]{2}{*}{$\begin{array}{l}\text { Wong et al. Clinical } \\
\text { guidelines for the } \\
\text { noninvasive management of } \\
\text { low back pain (2016) [86] }\end{array}$} & Recommended & $\begin{array}{l}\text { - Education: Advice and information promoting self-management, evidence-based information on } \\
\text { expected course and effective self-care options, advice to stay active. } \\
\text { - } \\
\text { Exercises: No recommendations for or against any specific type of exercise, consider } \\
\text { patient preferences. } \\
\text { - Manual therapy, including spinal manipulation } \\
\text { - } \quad \text { Multimodal rehabilitation: including physical and psychological interventions (e.g., } \\
\text { cognitive/behavioral approached and exercise). } \\
\text { - }\end{array}$ \\
\hline & Not recommended & $\begin{array}{l}\text { - } \quad \text { Muscle relaxants } \\
\text { - } \quad \text { Gabapentin } \\
\text { - } \quad \text { Passive modalities, including transcutaneous electrical nerve stimulation, laser, interferential therapy } \\
\text { and ultrasound. }\end{array}$ \\
\hline
\end{tabular}


Table 2. Cont.

Guideline

Recommendation for CLBP

- $\quad$ Exercise: Moderate-quality evidence for small improvements in pain relief and function when compared to no exercise or usual care. No evidence on which exercise regimen is best.

- Motor control exercise: Low-quality evidence for the effectiveness of motor control exercise (small improvements in pain and function) compared to minimal intervention, general exercise, and multimodal physical therapy. Low quality of evidence found no differences between motor control exercises plus exercise or exercise alone.

- $\quad$ Tai Chi: Low-quality evidence showed that Tai Chi results in moderate pain reduction compared to waitlist or no intervention.

Recommended _ _ Yoga: Low-quality evidence showed that yoga results in a small pain reduction compared to exercise.

- Psychological therapies: Low-quality evidence showed positive effects of progressive relaxation therapy, mindfulness relaxation, electromyography biofeedback training, operant therapy and cognitive behavioral therapy compared to waitlist. Low-quality evidence shows no difference between psychological therapies and exercise or physical therapy, and no difference between

Qaseem et al. Noninvasive treatments for acute, subacute and chronic low back pain (2017) [85]

Multidisciplinary rehabilitation: Moderate-quality evidence for effectiveness to improve pain and disability compared to usual care, no treatment, or physical therapy.

\begin{tabular}{cll}
\hline & & Pilates \\
Not Clear & - & Acupuncture: Low \\
& & to no treatment or \\
& - & Spinal manipulati \\
& - & Low-level laser th \\
& & \\
\hline \multirow{2}{*}{ Not recommended } & - & TENS \\
& - & Ultrasound \\
& - & Lumbar support \\
& &
\end{tabular}


Table 2. Cont.

Guideline

Recommendation for CLBP

- Self-management: Provide advice and information tailored to the patient's needs and capacities, including information on the nature of the pain, and encouragement to continue normal activities.

- $\quad$ Exercise: Consider group exercise programs, take into account the patient's specific needs, preferences and capabilities when choosing the type of exercise.

- Manual therapy (spinal manipulation, mobilization or soft tissue techniques): Can be used, but only as part of a treatment package including exercise, with or without psychological therapy.

Recommended - $\quad$ Cognitive behavioral therapy: As part of a treatment package, including exercise, with or without manual therapy.

- Multidisciplinary biopsychosocial rehabilitation: Consider a combined physical and psychological intervention incorporating cognitive behavioral techniques when significant psychosocial obstacles limit recovery, or when previous treatments have not been effective.

National Guideline Centre. NICE Guideline Low back pain and sciatica (2016) [40] 


\section{Promising Directions for Clinical Practice}

Over the past decades, scientific understanding of CLBP has increased substantially. This has shifted treatment approaches away from pure biomedical treatments to multimodal approaches that acknowledge the complex biopsychosocial nature of CLBP. The latter includes addressing lifestyle factors, like physical activity and sedentary behavior, exercise, stress, sleep, and nutritional aspects (Figure 1). In the general chronic pain population, the influence of lifestyle factors like (chronic) stress, insomnia and sleep problems, depression, smoking, alcohol, obesity and nutrition are already acknowledged [88-92]. Additionally, the overview of best evidence non-invasive rehabilitation for CLBP in this paper highlights the importance of physical activity and exercise therapy for CLBP management. Still, within CLBP management specifically, other lifestyle factors have received little attention in scientific literature so far. Yet, a multimodal lifestyle-centered approach (Figure 1) could lead to a long-term decrease of the psychological and socio-economic burden of chronic pain.

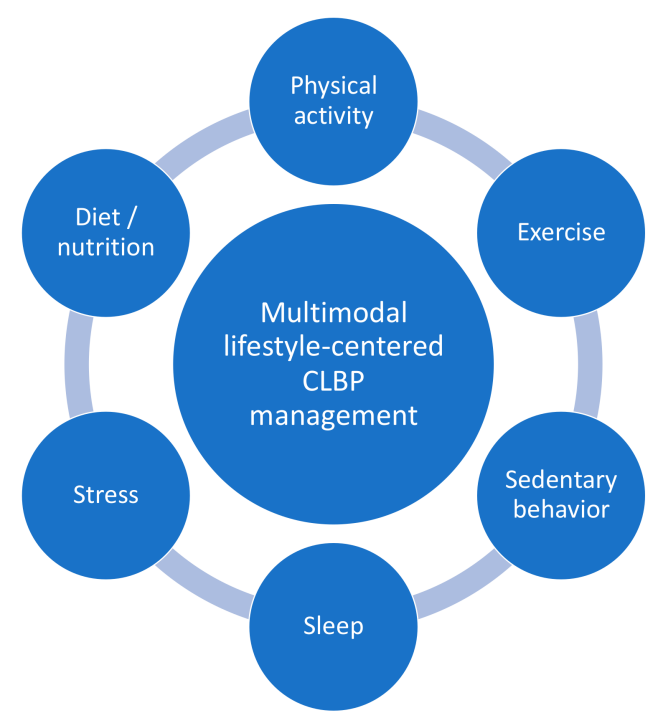

Figure 1. Promising direction for further research: a multimodal lifestyle-centered approach for people with chronic low back pain (CLBP).

Incorporating stress management in CLBP treatment could help patients to cope with everyday stressors, and leads to a clinically meaningful reduction in disability even at long-term (one year) follow-up [93]. Stress management can help to increase acceptance of physical discomfort and difficult emotions [93]. The advantage of a multimodal approach that addresses different lifestyle factors can be underscored by the interconnection between stress and sleep in people with CLBP [94]. Numerous studies report a strong association between anxiety levels and insomnia severity $[95,96]$, and daily life stress can negatively impact sleep [97]. As poor sleep acts as a precipitating and perpetuating factor [98], and can represent a barrier for effective chronic pain management [99], its importance for CLBP management is evident. Additionally, people with chronic pain will spontaneously engage in more physical activity following a better night of sleep [100], again underscoring the importance of a multimodal lifestyle-centered approach.

Similar to sleep, overweightness and obesity are risk factors for developing LBP, and are associated with more severe and debilitating pain as pain intensity and disability show dose-responses to Body Mass Index, waist circumference, percent fat, and fat mass [101-107]. Unfortunately, overweight and obesity are an often overlooked lifestyle factor of importance in CLBP, while overweight/obese people with CLBP are likely to have more complex needs requiring a focus on lifestyle factors [108]. A recent study examining a nonsurgical weight loss program (i.e., physical exercise plus changes in dietary behavior) found that people with CLBP $(n=46)$ not only lost body weight, but also experienced less pain and disability [109]. Given the uncontrolled nature of this study, methodologically-sound 
randomized controlled trials examining the added value of such an approach are needed. Yet, if therapists were to implement a weight reduction program for CLBP management, this program should include changes in diet, behavior and physical activity [109], given the American College of Sports Medicine Position Stand that a moderate dietary restriction combined with a physical activity program (i.e., a deficit of 500 to $700 \mathrm{kcal}$ on the energy balance) is effective and delivers long-term results [110]. Importantly, such multimodal lifestyle approach should primarily be implemented as a patient-centered approach, tailoring the included treatment aspects to the preferences and attitudes of the individual. This includes continuous (non-)verbal communication, education during all aspects of treatments, patient-defined goals, patient-empowerment, and a confident therapist who has sufficient social and interpersonal skills and shows specific knowledge [111]. To optimize the success rate of this approach, principles of self-monitoring, goal setting and feedback can also be integrated [112,113]. Given the need for behavioral changes in such a lifestyle approach, motivational interviewing techniques can help the therapist to overcome difficulties experienced by the patient to engage in this positive health behavior [114]. For example, consequences of an unhealthy lifestyle, as well as barriers for change, can be discussed, together with examples of how a better lifestyle can impact pain and quality of life, including a plan-of-action [115]. Motivational interviewing aims to develop autonomous motivation in the patient by increasing perceived competence, self-regulation and self-efficacy [115]. As higher self-efficacy is one of the key factors associated with better treatment outcome in chronic pain, motivational interviewing techniques are useful to consider even beyond CLBP management $[116,117]$. Clinicians and researchers should focus on this multimodal approach to CLBP to aim for long-term improvements in pain, disability and quality of life, rather than a short-term relief. As this approach could increase the empowerment of the patient and thus increase their personal control over the symptoms, the need for constant follow-up and supervision of a physiotherapist-and the related socio-economic costs—could be diminished.

\section{Conclusions}

Given the high prevalence of CLBP, and the overwhelming evidence available on its possible management, this paper aimed to give a clear overview of best evidence practice. To conclude, most physically inactive therapies should not be considered for CLBP management, except for pain neuroscience education and spinal manipulative therapy if combined with exercise therapy, with or without psychological therapy. Regarding active therapy, back schools, sensory discrimination training, proprioceptive exercises, and sling exercises should not be considered for CLBP management due to a lack of qualitative evidence and/or conflicting evidence. Exercise interventions, on the other hand, are recommended, but while all exercise modalities appear effective compared to minimal, passive/conservative or no intervention, there is no evidence that some specific types of exercises are superior to others. Therefore, we recommend choosing exercise modalities according with the patient's preferences and abilities. When combining exercise interventions with a psychological component, effects are better than an approach without psychological component and remain at long term.

\section{Key messages for CLBP rehabilitation}

- Do not consider the use of therapeutic ultrasound, kinesiotape, transcutaneous electrical nerve stimulation, massage and osteopathic interventions.

- $\quad$ Pain neuroscience education and spinal manipulative therapy can have positive effects but should not be used as stand-alone treatment. Consider these modalities only as part of a treatment package including exercise, with or without psychological therapy.

- Do not consider back school, sensory discrimination training, proprioceptive exercises, and sling exercises.

- Exercise therapy is highly recommended, but it is not clear which duration, intensity and methods of training are best. 
- Consider a combined physical and psychological intervention incorporating cognitive behavioral techniques to maintain positive effects at long-term.

Author Contributions: Conceptualization, A.M, K.I. and J.N.; Literature search and data extraction, A.M.; Writing, Original Draft Preparation, A.M..; Writing, Review \& Editing, all authors; Supervision, J.N.

Acknowledgments: Anneleen Malfliet, Kelly Ickmans, and Eva Huysmans funded by the Research Foundation Flanders (FWO), Belgium. This work is partially funded by the Berekuyl Academy Chair, funded by the European College for Lymphatic Therapy, The Netherlands, and awarded to Jo Nijs, Vrije Universiteit Brussel, Belgium. Iris Coppieters and Thomas Bilterys are both funded by the Applied Biomedical Research Program (TBM) of the Agency for Innovation by Science and Technology (IWT) and the Research Foundation Flanders (FWO), Belgium.

Conflicts of Interest: Jo Nijs has co-authored a Dutch book for clinicians on pain neuroscience education, but the royalties for that book are collected by the Vrije Universiteit Brussel and not him personally. Besides that, the authors have no conflict of interest to disclose.

\section{References}

1. Clark, S.; Horton, R. Low Back Pain: A Major Global Challenge. Lancet 2018, 391, 2302. [CrossRef]

2. Meucci, R.D.; Fassa, A.G.; Faria, N.M. Prevalence of Chronic Low Back Pain: Systematic Review. Rev. Saude Publica 2015, 49, 73. [CrossRef] [PubMed]

3. Hurwitz, E.L.; Randhawa, K.; Yu, H.; Cote, P.; Haldeman, S. The Global Spine Care Initiative: A Summary of the Global Burden of Low Back and Neck Pain Studies. Eur. Spine J. 2018, 27, 796-801. [CrossRef] [PubMed]

4. James, S.L.; Abate, D.; Abate, K.H.; Abay, S.M.; Abbafati, C.; Abbasi, N.; Abbastabar, H.; Abd-Allah, F.; Abdela, J.; Abdelalim, A.; et al. Global, Regional, and National Incidence, Prevalence, and Years Lived with Disability for 354 Diseases and Injuries for 195 Countries and Territories, 1990-2017: A Systematic Analysis for the Global Burden of Disease Study 2017. Lancet 2018, 392, 1789-1858. [CrossRef]

5. Ferreira, M.L.; Machado, G.; Latimer, J.; Maher, C.; Ferreira, P.H.; Smeets, R.J. Factors Defining Care-Seeking in Low Back Pain-A Meta-Analysis of Population Based Surveys. Eur. J. Pain 2010, 14, 747.e1-747.e7. [CrossRef] [PubMed]

6. Gore, M.; Sadosky, A.; Stacey, B.R.; Tai, K.; Leslie, D. The Burden of Chronic Low Back Pain: Clinical Comorbidities, Treatment Patterns, and Health Care Costs in Usual Care Settings. Spine 2012, 37, E668-E677. [CrossRef] [PubMed]

7. Balague, F.; Mannion, A.F.; Pellise, F.; Cedraschi, C. Non-Specific Low Back Pain. Lancet 2012, 379, $482-491$. [CrossRef]

8. O'Connell, N.E.; Cook, C.E.; Wand, B.M.; Ward, S.P. Clinical Guidelines for Low Back Pain: A Critical Review of Consensus and Inconsistencies across three major guidelines. Best Pract. Res. Clin. Rheumatol. 2016, 30, 968-980. [CrossRef]

9. Fraenkel, L.; Falzer, P.; Fried, T.; Kohler, M.; Peters, E.; Kerns, R.; Leventhal, H. Measuring Pain Impact Versus Pain Severity Using a Numeric Rating Scale. J. Gen. Intern. Med. 2012, 27, 555-560. [CrossRef]

10. Turk, D.C.; Fillingim, R.B.; Ohrbach, R.; Patel, K.V. Assessment of Psychosocial and Functional Impact of Chronic Pain. J. Pain 2016, 17, T21-T49. [CrossRef]

11. Noori, S.A.; Rasheed, A.; Aiyer, R.; Jung, B.; Bansal, N.; Chang, K.; Ottestad, E.; Gulati, A. Therapeutic Ultrasound for Pain Management in Chronic Low Back Pain and Chronic Neck Pain: A Systematic Review. Pain Med. 2019. [CrossRef] [PubMed]

12. Li, Y.; Yin, Y.; Jia, G.; Chen, H.; Yu, L.; Wu, D. Effects of Kinesiotape on Pain and Disability in Individuals with Chronic Low Back Pain: A Systematic Review and Meta-Analysis of Randomized Controlled Trials. Clin. Rehabil. 2018, 33, 596-606. [CrossRef] [PubMed]

13. Wood, L.; Hendrick, P.A. A Systematic Review and Meta-Analysis of Pain Neuroscience Education for Chronic Low Back Pain: Short-and Long-Term Outcomes of Pain and Disability. Eur. J. Pain 2019, 23, $234-249$. [CrossRef] [PubMed]

14. Resende, L.; Merriwether, E.; Rampazo, E.P.; Dailey, D.; Embree, J.; Deberg, J.; Liebano, R.E.; Sluka, K.A. Meta-Analysis of Transcutaneous Electrical Nerve Stimulation for Relief of Spinal Pain. Eur. J. Pain 2018, 22, 663-678. [CrossRef] [PubMed] 
15. Wu, L.C.; Weng, P.W.; Chen, C.H.; Huang, Y.Y.; Tsuang, Y.H.; Chiang, C.J. Literature Review and Meta-Analysis of Transcutaneous Electrical Nerve Stimulation in Treating Chronic Back Pain. Reg. Anesth. Pain Med. 2018, 43, 425-433. [CrossRef] [PubMed]

16. Furlan, A.D.; Giraldo, M.; Baskwill, A.; Irvin, E.; Imamura, M. Massage for Low-Back Pain. Cochrane Database Syst. Rev. 2015, 9, CD001929. [CrossRef] [PubMed]

17. Orrock, P.J.; Myers, S.P. Osteopathic Intervention in Chronic Non-Specific Low Back Pain: A Systematic Review. BMC Musculoskelet. Disord. 2013, 14, 129. [CrossRef]

18. Rubinstein, S.M.; de Zoete, A.; van Middelkoop, M.; Assendelft, W.J.J.; de Boer, M.R.; van Tulder, M.W. Benefits and Harms of Spinal Manipulative Therapy for the Treatment of Chronic Low Back Pain: Systematic Review and Meta-Analysis of Randomised Controlled Trials. BMJ 2019, 364, 1689. [CrossRef]

19. Hajihasani, A.; Rouhani, M.; Salavati, M.; Hedayati, R.; Kahlaee, A.H. The Influence of Cognitive Behavioral Therapy on Pain, Quality of Life, and Depression in Patients Receiving Physical Therapy for Chronic Low Back Pain: A Systematic Review. PMR 2019,11, 167-176. [CrossRef]

20. Zhang, Q.; Jiang, S.; Young, L.; Li, F. The Effectiveness of Group-Based Physiotherapy-Led Behavioral Psychological Interventions on Adults with Chronic Low Back Pain: A Systematic Review and Meta-Analysis. Am. J. Phys. Med. Rehabil. 2019, 98, 215-225. [CrossRef]

21. Vanti, C.; Andreatta, S.; Borghi, S.; Guccione, A.A.; Pillastrini, P.; Bertozzi, L. The Effectiveness of Walking Versus Exercise on Pain and Function in Chronic Low Back Pain: A Systematic Review and Meta-Analysis of Randomized Trials. Disabil. Rehabil. 2019, 41, 622-632. [CrossRef]

22. Sitthipornvorakul, E.; Klinsophon, T.; Sihawong, R.; Janwantanakul, P. The Effects of Walking Intervention in Patients with Chronic Low Back Pain: A Meta-Analysis of Randomized Controlled Trials. Musculoskelet. Sci. Pract. 2018, 34, 38-46. [CrossRef]

23. van Erp, R.M.A.; Huijnen, I.P.J.; Jakobs, M.L.G.; Kleijnen, J.; Smeets, R. Effectiveness of Primary Care Interventions Using a Biopsychosocial Approach in Chronic Low Back Pain: A Systematic Review. Pain Pract. 2019, 19, 224-241. [CrossRef]

24. Wewege, M.A.; Booth, J.; Parmenter, B.J. Aerobic Vs. Resistance Exercise for Chronic Non-Specific Low Back Pain: A Systematic Review and Meta-Analysis. J. Back Musculoskelet. Rehabil. 2018, 31, 889-899. [CrossRef]

25. Luomajoki, H.A.; Beltran, M.B.B.; Careddu, S.; Bauer, C.M. Effectiveness of Movement Control Exercise on Patients with Non-Specific Low Back Pain and Movement Control Impairment: A Systematic Review and Meta-Analysis. Musculoskelet. Sci. Pract. 2018, 36, 1-11. [CrossRef]

26. Parreira, P.; Heymans, M.W.; van Tulder, M.W.; Esmail, R.; Koes, B.W.; Poquet, N.; Lin, C.C.; Maher, C.G. Back Schools for Chronic Non-Specific Low Back Pain. Cochrane Database Syst. Rev. 2017, 8, CD011674. [CrossRef]

27. Du, S.; Hu, L.; Dong, J.; Xu, G.; Chen, X.; Jin, S.; Zhang, H.; Yin, H. Self-Management Program for Chronic Low Back Pain: A Systematic Review and Meta-Analysis. Patient Educ. Couns. 2017, 100, 37-49. [CrossRef]

28. López-de-Uralde-Villanueva, I.; Muñoz-García, D.; Gil-Martínez, A.; Pardo-Montero, J.; Muñoz-Plata, R.; Angulo-Díaz-Parreño, S.; Gómez-Martínez, M.; la Touche, R. A Systematic Review and Meta-Analysis on the Effectiveness of Graded Activity and Graded Exposure for Chronic Nonspecific Low Back Pain. Pain Med. 2016, 17, 172-188. [CrossRef]

29. Saragiotto, B.T.; Maher, C.G.; Yamato, T.P.; Costa, L.O.; Costa, L.C.; Ostelo, R.W.; Macedo, L.G. Motor Control Exercise for Nonspecific Low Back Pain: A Cochrane Review. Spine 2016, 41, 1284-1295. [CrossRef]

30. Kalin, S.; Rausch-Osthoff, A.K.; Bauer, C.M. What Is the Effect of Sensory Discrimination Training on Chronic Low Back Pain? A Systematic Review. BMC Musculoskelet. Disord. 2016, 17, 143. [CrossRef]

31. Yamato, T.P.; Maher, C.G.; Saragiotto, B.T.; Hancock, M.J.; Ostelo, R.W.; Cabral, C.M.; Costa, L.C.; Costa, L.O. Pilates for Low Back Pain: Complete Republication of a Cochrane Review. Spine 2016, 41, 1013-1021. [CrossRef] [PubMed]

32. Kamper, S.J.; Apeldoorn, A.T.; Chiarotto, A.; Smeets, R.J.; Ostelo, R.W.; Guzman, J.; van Tulder, M.W. Multidisciplinary Biopsychosocial Rehabilitation for Chronic Low Back Pain: Cochrane Systematic Review and Meta-Analysis. BMJ 2015, 350, h444. [CrossRef] [PubMed]

33. Searle, A.; Spink, M.; Ho, A.; Chuter, V. Exercise Interventions for the Treatment of Chronic Low Back Pain: A Systematic Review and Meta-Analysis of Randomised Controlled Trials. Clin. Rehabil. 2015, 29, 1155-1167. [CrossRef] [PubMed] 
34. McCaskey, M.A.; Schuster-Amft, C.; Wirth, B.; Suica, Z.; de Bruin, E.D. Effects of Proprioceptive Exercises on Pain and Function in Chronic Neck- and Low Back Pain Rehabilitation: A Systematic Literature Review. BMC Musculoskelet. Disord. 2014, 15, 382. [CrossRef] [PubMed]

35. Yue, Y.S.; Wang, X.D.; Xie, B.; Li, Z.H.; Chen, B.L.; Wang, X.Q.; Zhu, Y. Sling Exercise for Chronic Low Back Pain: A Systematic Review and Meta-Analysis. PLoS ONE 2014, 9, e99307. [CrossRef]

36. Holtzman, S.; Beggs, R.T. Yoga for Chronic Low Back Pain: A Meta-Analysis of Randomized Controlled Trials. Pain Res. Manag. 2013, 18, 267-272. [CrossRef] [PubMed]

37. Hoffman, B.M.; Papas, R.K.; Chatkoff, D.K.; Kerns, R.D. Meta-Analysis of Psychological Interventions for Chronic Low Back Pain. Health Psychol. 2007, 26, 1-9. [CrossRef]

38. Malfliet, A.; Kregel, J.; Meeus, M.; Roussel, N.; Danneels, L.; Cagnie, B.; Dolphens, M.; Nijs, J. Blended Learning Pain Neuroscience Education for People with Chronic Spinal Pain: A Randomized-Controlled Multi-Centre Trial. Phys. Ther. 2017, 98, 357-358. [CrossRef]

39. Picavet, H.S.J.; Vlaeyen, J.W.S.; Schouten, J.S.A.G. Pain Catastrophizing and Kinesiophobia: Predictors of Chronic Low Back Pain. Am. J. Epidemiol. 2002, 156, 1028-1034. [CrossRef]

40. National Institute for Health and Care Excellence. Nice Guidelines: Low Back Pain and Sciatica in over 16s: Assessment and Management; National Institute for Health and Care Excellence: London, UK, 2016.

41. Van Ittersum, M.W.; Van Wilgen, C.P.; Van der Schans, C.P.; Lambrecht, L.; Groothoff, J.W.; Nijs, J. Written Pain Neuroscience Education in Fibromyalgia: A Multicenter Randomized Controlled Trial. Pain Pract. 2013, 14, 689-700. [CrossRef]

42. Nijs, J.; Meeus, M. Five Requirements for Effective Pain Neuroscience Education in Physiotherapy Practice. nuzzel.com. 2015. Available online: http://www.paininmotion.be/blog/detail/five-requirements-effectivepain-neuroscience-education-physiotherapy-practice (accessed on 5 May 2019).

43. Bodes Pardo, G.; Girbes, E.L.; Roussel, N.A.; Izquierdo, T.G.; Penick, V.J.; Martin, D.P. Pain Neurophysiology Education and Therapeutic Exercise for Patients with Chronic Low Back Pain: A Single-Blind Randomized Controlled Trial. Arch. Phys. Med. Rehabil. 2018, 99, 338-347. [CrossRef] [PubMed]

44. Butler, D.S.; Moseley, G.L. Explain Pain; Noigroup Publications: Adelaide, Australia, 2003.

45. Van Wilgen, C.P.; Nijs, J. Pijneducatie-Een Praktische Handleiding Voor (Para)Medici; Bohn Stafleu van Loghum: Houten, The Netherlands, 2010.

46. Pain in Motion. Tools for Clinical Practice. Available online: http://www.paininmotion.be/education/toolsfor-clinical-practice (accessed on 5 May 2019).

47. Rubinstein, S.M.; van Middelkoop, M.; Assendelft, W.J.; de Boer, M.R.; van Tulder, M.W. Spinal Manipulative Therapy for Chronic Low-Back Pain. Cochrane Database Syst. Rev. 2011, 16, CD008112.

48. O'Keeffe, M.; O'Connell, N.E. Letter to the Editor. Response Letter To: Benefits and Harms of Spinal Manipulative Therapy for the Treatment of Chronic Low Back Pain: Systematic Review and Meta-Analysis of Randomised Controlled Trials. BMJ 2019, 364, 1689.

49. de Oliveira, R.F.; Liebano, R.E.; Lda, C.C.; Rissato, L.L.; Costa, L.O. Immediate Effects of Region-Specific and Non-Region-Specific Spinal Manipulative Therapy in Patients with Chronic Low Back Pain: A Randomized Controlled Trial. Phys. Ther. 2013, 93, 748-756. [CrossRef] [PubMed]

50. Louw, A.; Nijs, J.; Puentedura, E.J. A Clinical Perspective on a Pain Neuroscience Education Approach to Manual Therapy. J. Man. Manip. Ther. 2017, 25, 160-168. [CrossRef] [PubMed]

51. Puentedura, E.J.; Flynn, T. Combining Manual Therapy with Pain Neuroscience Education in the Treatment of Chronic Low Back Pain: A Narrative Review of the Literature. Physiother. Theory Pract. 2016, 32, 408-414. [CrossRef] [PubMed]

52. Bialosky, J.E.; George, S.Z.; Bishop, M.D. How Spinal Manipulative Therapy Works: Why Ask Why? J. Orthop. Sports Phys. Ther. 2008, 38, 293-295. [CrossRef]

53. Nijs, J.; Roussel, N.; van Wilgen, C.P.; Koke, A.; Smeets, R. Thinking Beyond Muscles and Joints: Therapists' and Patients' Attitudes and Beliefs Regarding Chronic Musculoskeletal Pain Are Key to Applying Effective Treatment. Man. Ther. 2013, 18, 96-102. [CrossRef]

54. Lluch Girbes, E.; Meeus, M.; Baert, I.; Nijs, J. Balancing "Hands-on" with "Hands-Off" Physical Therapy Interventions for the Treatment of Central Sensitization Pain in Osteoarthritis. Man. Ther. 2015, 20, 349-352. [CrossRef]

55. Naugle, K.M.; Fillingim, R.B.; Riley, J.L., III. A Meta-Analytic Review of the Hypoalgesic Effects of Exercise. J. Pain 2012, 13, 1139-1150. [CrossRef] 
56. Steiger, F.; Wirth, B.; de Bruin, E.D.; Mannion, A.F. Is a Positive Clinical Outcome after Exercise Therapy for Chronic Non-Specific Low Back Pain Contingent Upon a Corresponding Improvement in the Targeted Aspect(S) of Performance? A Systematic Review. Eur. Spine J. 2012, 21, 575-598. [CrossRef] [PubMed]

57. Booth, J.; Moseley, G.L.; Schiltenwolf, M.; Cashin, A.; Davies, M.; Hubscher, M. Exercise for Chronic Musculoskeletal Pain: A Biopsychosocial Approach. Musculoskelet. Care 2017, 15, 413-421. [CrossRef] [PubMed]

58. Walti, P.; Kool, J.; Luomajoki, H. Short-Term Effect on Pain and Function of Neurophysiological Education and Sensorimotor Retraining Compared to Usual Physiotherapy in Patients with Chronic or Recurrent Non-Specific Low Back Pain, a Pilot Randomized Controlled Trial. BMC Musculoskelet. Disord. 2015, 16, 83. [CrossRef] [PubMed]

59. Vibe Fersum, K.; O'Sullivan, P.; Skouen, J.S.; Smith, A.; Kvale, A. Efficacy of Classification-Based Cognitive Functional Therapy in Patients with Non-Specific Chronic Low Back Pain: A Randomized Controlled Trial. Eur. J. Pain 2013, 17, 916-928. [CrossRef] [PubMed]

60. Von Korff, M.; Balderson, B.H.; Saunders, K.; Miglioretti, D.L.; Lin, E.H.; Berry, S.; Moore, J.E.; Turner, J.A. A Trial of an Activating Intervention for Chronic Back Pain in Primary Care and Physical Therapy Settings. Pain 2005, 113, 323-330. [CrossRef] [PubMed]

61. Linton, S.J.; Boersma, K.; Jansson, M.; Svard, L.; Botvalde, M. The Effects of Cognitive-Behavioral and Physical Therapy Preventive Interventions on Pain-Related Sick Leave: A Randomized Controlled Trial. Clin. J. Pain 2005, 21, 109-119. [CrossRef] [PubMed]

62. Monticone, M.; Ferrante, S.; Rocca, B.; Baiardi, P.; Farra, F.D.; Foti, C. Effect of a Long-Lasting Multidisciplinary Program on Disability and Fear-Avoidance Behaviors in Patients with Chronic Low Back Pain: Results of a Randomized Controlled Trial. Clin. J. Pain 2013, 29, 929-938. [CrossRef]

63. Lambeek, L.C.; van Mechelen, W.; Knol, D.L.; Loisel, P.; Anema, J.R. Randomised Controlled Trial of Integrated Care to Reduce Disability from Chronic Low Back Pain in Working and Private Life. BMJ 2010, 340, c1035. [CrossRef]

64. Nicholas, M.K.; Wilson, P.H.; Goyen, J. Operant-Behavioural and Cognitive-Behavioural Treatment for Chronic Low Back Pain. Behav. Res. Ther. 1991, 29, 225-238. [CrossRef]

65. Strand, L.I.; Ljunggren, A.E.; Haldorsen, E.M.; Espehaug, B. The Impact of Physical Function and Pain on Work Status at 1-Year Follow-up in Patients with Back Pain. Spine 2001, 26, 800-808. [CrossRef]

66. Roche, G.; Ponthieux, A.; Parot-Shinkel, E.; Jousset, N.; Bontoux, L.; Dubus, V.; Penneau-Fontbonne, D.; Roquelaure, Y.; Legrand, E.; Colin, D.; et al. Comparison of a Functional Restoration Program with Active Individual Physical Therapy for Patients with Chronic Low Back Pain: A Randomized Controlled Trial. Arch. Phys. Med. Rehabil. 2007, 88, 1229-1235. [CrossRef]

67. Roche-Leboucher, G.; Petit-Lemanac'h, A.; Bontoux, L.; Dubus-Bausiere, V.; Parot-Shinkel, E.; Fanello, S.; Penneau-Fontbonne, D.; Fouquet, N.; Legrand, E.; Roquelaure, Y.; et al. Multidisciplinary Intensive Functional Restoration Versus Outpatient Active Physiotherapy in Chronic Low Back Pain: A Randomized Controlled Trial. Spine 2011, 36, 2235-2242. [CrossRef]

68. Bendix, A.F.; Bendix, T.; Hæstrup, C.; Busch, E. A Prospective, Randomized 5-Year Follow-up Study of Functional Restoration in Chronic Low Back Pain Patients. Eur. Spine J. 1998, 7, 111-119. [CrossRef]

69. Bendix, A.F.; Bendix, T.; Ostenfeld, S.; Bush, E.; Andersen, A. Active Treatment Programs for Patients with Chronic Low Back Pain: A Prospective, Randomized, Observer-Blinded Study. Eur. Spine J. 1995, 4, 148-152. [CrossRef]

70. Kool, J.; Bachmann, S.; Oesch, P.; Knuesel, O.; Ambergen, T.; de Bie, R.; van den Brandt, P. Function-Centered Rehabilitation Increases Work Days in Patients with Nonacute Nonspecific Low Back Pain: 1-Year Results from a Randomized Controlled Trial. Arch. Phys. Med. Rehabil. 2007, 88, 1089-1094. [CrossRef]

71. Streilbelt, M.; Thren, K.; Muller-Fahrnow, W. Effects of Fce-Based Multidisciplinary Rehabilitation in Patients with Chronic Musculoskeletal Disorders-Results of a Randomized Controlled Trial. Physikalische Medizin Rehabilitationsmedizin Kurortmedizin 2009, 19, 34-41.

72. Sletten, C.D.; Kurklinsky, S.; Chinburapa, V.; Ghazi, S. Economic Analysis of a Comprehensive Pain Rehabilitation Program: A Collaboration between Florida Blue and Mayo Clinic Florida. Pain Med. 2015, 16, 898-904. [CrossRef]

73. Evans, J.R.; Benore, E.; Banez, G.A. The Cost-Effectiveness of Intensive Interdisciplinary Pediatric Chronic Pain Rehabilitation. J. Pediatr. Psychol. 2015, 41, 849-856. [CrossRef] 
74. Gatchel, R.J.; McGeary, D.D.; McGeary, C.A.; Lippe, B. Interdisciplinary Chronic Pain Management: Past, Present, and Future. Am. Psychol. 2014, 69, 119-130. [CrossRef]

75. Malfliet, A.; Kregel, J.; Coppieters, I.; de Pauw, R.; Meeus, M.; Roussel, N.; Cagnie, B.; Danneels, L.; Nijs, J. Effect of Pain Neuroscience Education Combined with Cognition-Targeted Motor Control Training on Chronic Spinal Pain: A Randomized Clinical Trial. JAMA Neurol. 2018, 75, 808-817. [CrossRef]

76. Malfliet, A.; Kregel, J.; Meeus, M.; Cagnie, B.; Roussel, N.; Dolphens, M.; Danneels, L.; Nijs, J. Applying Contemporary Neuroscience in Exercise Interventions for Chronic Spinal Pain: Treatment Protocol. Braz. J. Phys. Ther. 2017, 21, 378-387. [CrossRef]

77. Woods, M.P.; Asmundson, G.J. Evaluating the Efficacy of Graded in Vivo Exposure for the Treatment of Fear in Patients with Chronic Back Pain: A Randomized Controlled Clinical Trial. Pain 2008, 136, 271-280. [CrossRef]

78. Vlaeyen, J.W.; de Jong, J.; Geilen, M.; Heuts, P.H.; van Breukelen, G. The Treatment of Fear of Movement/(Re)Injury in Chronic Low Back Pain: Further Evidence on the Effectiveness of Exposure in Vivo. Clin. J. Pain 2002, 18, 251-261. [CrossRef]

79. Tully, M.A.; Cupples, M.E.; Hart, N.D.; McEneny, J.; McGlade, K.J.; Chan, W.S.; Young, I.S. Randomised Controlled Trial of Home-Based Walking Programmes at and Below Current Recommended Levels of Exercise in Sedentary Adults. J. Epidemiol. Community Health 2007, 61, 778-783. [CrossRef]

80. Tschentscher, M.; Niederseer, D.; Niebauer, J. Health Benefits of Nordic Walking: A Systematic Review. Am. J. Prev. Med. 2013, 44, 76-84. [CrossRef]

81. Chetty, L. A Critical Review of Low Back Pain Guidelines. Workplace Health Saf. 2017, 65, 388-394. [CrossRef]

82. Bekkering, G.E.; Hendriks, E.; Koes, B.; Oostendorp, R.A.B.; Rwjg, O.; Jmc, T.; Tulder, M. Dutch Physiotherapy Guidelines for Low Back Pain. Physiotherapy 2003, 89, 82-96. [CrossRef]

83. Australian Acute Musculoskeletal Pain Guidelines Group. Evidencebased Management of Acute Musculoskeletal Pain; Australian Academic Press: Brisbane, Australia, 2004.

84. van Tulder, M.; Becker, A.; Bekkering, T.; Breen, A.; del Real, M.T.; Hutchinson, A.; Koes, B.; Laerum, E.; Malmivaara, A. Chapter 3. European Guidelines for the Management of Acute Nonspecific Low Back Pain in Primary Care. Eur. Spine J. 2006, 15, S169-S191. [CrossRef]

85. Qaseem, A.; Wilt, T.J.; McLean, R.M.; Forciea, M.A. Noninvasive Treatments for Acute, Subacute, and Chronic Low Back Pain: A Clinical Practice Guideline from the American College of Physicians. Ann. Intern. Med. 2017, 166, 514-530. [CrossRef]

86. Wong, J.J.; Cote, P.; Sutton, D.A.; Randhawa, K.; Yu, H.; Varatharajan, S.; Goldgrub, R.; Nordin, M.; Gross, D.P.; Shearer, H.M.; et al. Clinical Practice Guidelines for the Noninvasive Management of Low Back Pain: A Systematic Review by the Ontario Protocol for Traffic Injury Management (Optima) Collaboration. Eur. J. Pain 2016, 21, 201-216. [CrossRef]

87. White, N.T.; Delitto, A.; Manal, T.J.; Miller, S. The American Physical Therapy Association's Top Five Choosing Wisely Recommendations. Phys. Ther. 2015, 95, 9-24. [CrossRef]

88. Morin, C.M.; Gibson, D.; Wade, J. Self-Reported Sleep and Mood Disturbance in Chronic Pain Patients. Clin. J. Pain 1998, 14, 311-314. [CrossRef]

89. Finan, P.H.; Goodin, B.R.; Smith, M.T. The Association of Sleep and Pain: An Update and a Path Forward. J. Pain 2013, 14, 1539-1552. [CrossRef]

90. Finan, P.H.; Smith, M.T. The Comorbidity of Insomnia, Chronic Pain, and Depression: Dopamine as a Putative Mechanism. Sleep Med. Rev. 2013, 17, 173-183. [CrossRef]

91. Van Hecke, O.; Torrance, N.; Smith, B.H. Chronic Pain Epidemiology-Where Do Lifestyle Factors Fit In? Br. J. Pain 2013, 7, 209-217. [CrossRef]

92. Abdallah, C.G.; Geha, P. Chronic Pain and Chronic Stress: Two Sides of the Same Coin? Chronic Stress 2017, 1. [CrossRef]

93. Cherkin, D.C.; Sherman, K.J.; Balderson, B.H.; Cook, A.J.; Anderson, M.L.; Hawkes, R.J.; Hansen, K.E.; Turner, J.A. Effect of Mindfulness-Based Stress Reduction Vs Cognitive Behavioral Therapy or Usual Care on Back Pain and Functional Limitations in Adults with Chronic Low Back Pain: A Randomized Clinical Trial. JAMA 2016, 315, 1240-1249. [CrossRef]

94. Tang, N.K.Y.; Wright, K.J.; Salkovskis, P.M. Prevalence and Correlates of Clinical Insomnia Co-Occurring with Chronic Back Pain. J. Sleep Res. 2007, 16, 85-95. [CrossRef] 
95. Denis, D.; Akhtar, R.; Holding, B.C.; Murray, C.; Panatti, J.; Claridge, G.; Sadeh, A.; Barclay, N.L.; O'Leary, R.; Maughan, B.; et al. Externalizing Behaviors and Callous-Unemotional Traits: Different Associations with Sleep Quality. Sleep 2017, 40, zsx070. [CrossRef]

96. Nakamura, M.; Nagamine, T. Neuroendocrine, Autonomic, and Metabolic Responses to an Orexin Antagonist, Suvorexant, in Psychiatric Patients with Insomnia. Innov. Clin. Neurosci. 2017, 14, 30-37.

97. Kim, E.J.; Dimsdale, J.E. The Effect of Psychosocial Stress on Sleep: A Review of Polysomnographic Evidence. Behav. Sleep Med. 2007, 5, 256-278. [CrossRef]

98. Jungquist, C.R.; O’Brien, C.; Matteson-Rusby, S.; Smith, M.T.; Pigeon, W.R.; Xia, Y.; Lu, N.; Perlis, M.L. The Efficacy of Cognitive-Behavioral Therapy for Insomnia in Patients with Chronic Pain. Sleep Med. 2010, 11, 302-309. [CrossRef]

99. Pigeon, W.R.; Moynihan, J.; Matteson-Rusby, S.; Jungquist, C.R.; Xia, Y.; Tu, X.; Perlis, M.L. Comparative Effectiveness of Cbt Interventions for Co-Morbid Chronic Pain \& Insomnia: A Pilot Study. Behav. Res. Ther. 2012, 50, 685-689.

100. Tang, N.K.Y.; Sanborn, A.N. Better Quality Sleep Promotes Daytime Physical Activity in Patients with Chronic Pain? A Multilevel Analysis of the within-Person Relationship. PLoS ONE 2014, 9, e92158. [CrossRef]

101. Vismara, L.; Menegoni, F.; Zaina, F.; Galli, M.; Negrini, S.; Capodaglio, P. Effect of Obesity and Low Back Pain on Spinal Mobility: A Cross Sectional Study in Women. J. Neuroeng. Rehabil. 2010, 7, 3. [CrossRef]

102. Shiri, R.; Karppinen, J.; Leino-Arjas, P.; Solovieva, S.; Viikari-Juntura, E. The Association between Obesity and Low Back Pain: A Meta-Analysis. Am. J. Epidemiol. 2010, 171, 135-154. [CrossRef]

103. Hershkovich, O.; Friedlander, A.; Gordon, B.; Arzi, H.; Derazne, E.; Tzur, D.; Shamis, A.; Afek, A. Associations of Body Mass Index and Body Height with Low Back Pain in 829,791 Adolescents. Am. J. Epidemiol. 2013, 178, 603-609. [CrossRef]

104. Paulis, W.D.; Silva, S.; Koes, B.W.; van Middelkoop, M. Overweight and Obesity Are Associated with Musculoskeletal Complaints as Early as Childhood: A Systematic Review. Obes. Rev. 2014, 15, 52-67. [CrossRef]

105. Zhang, T.T.; Liu, Z.; Liu, Y.L.; Zhao, J.J.; Liu, D.W.; Tian, Q.B. Obesity as a Risk Factor for Low Back Pain: A Meta-Analysis. Clin. Spine Surg. 2018, 31, 22-27. [CrossRef]

106. Hussain, S.M.; Urquhart, D.M.; Wang, Y.; Shaw, J.E.; Magliano, D.J.; Wluka, A.E.; Cicuttini, F.M. Fat Mass and Fat Distribution Are Associated with Low Back Pain Intensity and Disability: Results from a Cohort Study. Arthritis Res. Ther. 2017, 19, 26. [CrossRef]

107. Dario, A.B.; Ferreira, M.L.; Refshauge, K.; Sanchez-Romera, J.F.; Luque-Suarez, A.; Hopper, J.L.; Ordonana, J.R.; Ferreira, P.H. Are Obesity and Body Fat Distribution Associated with Low Back Pain in Women? A Population-Based Study of 1128 Spanish Twins. Eur. Spine J. 2016, 25, 1188-1195. [CrossRef]

108. Williams, A.; Wiggers, J.; O’Brien, K.M.; Wolfenden, L.; Yoong, S.; Campbell, E.; Robson, E.; McAuley, J.; Haskins, R.; Kamper, S.J.; et al. A Randomised Controlled Trial of a Lifestyle Behavioural Intervention for Patients with Low Back Pain, Who Are Overweight or Obese: Study Protocol. BMC Musculoskelet. Disord. 2016, 17, 70. [CrossRef]

109. Roffey, D.M.; Ashdown, L.C.; Dornan, H.D.; Creech, M.J.; Dagenais, S.; Dent, R.M.; Wai, E.K. Pilot Evaluation of a Multidisciplinary, Medically Supervised, Nonsurgical Weight Loss Program on the Severity of Low Back Pain in Obese Adults. Spine J. 2011, 11, 197-204. [CrossRef]

110. Donnelly, J.E.; Blair, S.N.; Jakicic, J.M.; Manore, M.M.; Rankin, J.W.; Smith, B.K. American College of Sports Medicine Position Stand. Appropriate Physical Activity Intervention Strategies for Weight Loss and Prevention of Weight Regain for Adults. Med. Sci. Sports Exerc. 2009, 41, 459-471. [CrossRef]

111. Wijma, A.J.; Bletterman, A.N.; Clark, J.R.; Vervoort, S.; Beetsma, A.; Keizer, D.; Nijs, J.; van Wilgen, C.P. Patient-Centeredness in Physiotherapy: What Does It Entail? A Systematic Review of Qualitative Studies. Physiother Theory Pract. 2017, 33, 825-840. [CrossRef]

112. Perez, R.B.; Dixon, S.; Culver, S.; Sletten, C.D. Intensive Interdisciplinary Treatment for a Patient with Coexisting Pain and Obesity: A Case Study. Obes. Res. Clin. Pract. 2018, 12, 397-400. [CrossRef]

113. Michie, S.; Richardson, M.; Johnston, M.; Abraham, C.; Francis, J.; Hardeman, W.; Eccles, M.P.; Cane, J.; Wood, C.E. The Behavior Change Technique Taxonomy (V1) of 93 Hierarchically Clustered Techniques: Building an International Consensus for the Reporting of Behavior Change Interventions. Ann. Behav. Med. 2013, 46, 81-95. [CrossRef] 
114. Briggs, A.M.; Jordan, J.E.; O’Sullivan, P.B.; Buchbinder, R.; Burnett, A.F.; Osborne, R.H.; Straker, L.M. Individuals with Chronic Low Back Pain Have Greater Difficulty in Engaging in Positive Lifestyle Behaviours Than Those without Back Pain: An Assessment of Health Literacy. BMC Musculoskelet. Disord. 2011, 12, 161. [CrossRef]

115. Lee, H.; Wiggers, J.; Kamper, S.J.; Williams, A.; O’Brien, K.M.; Hodder, R.K.; Wolfenden, L.; Yoong, S.L.; Campbell, E.; Haskins, R.; et al. Mechanism Evaluation of a Lifestyle Intervention for Patients with Musculoskeletal Pain Who Are Overweight or Obese: Protocol for a Causal Mediation Analysis. BMJ Open 2017, 7, e014652. [CrossRef]

116. Miles, C.L.; Pincus, T.; Carnes, D.; Homer, K.E.; Taylor, S.J.; Bremner, S.A.; Rahman, A.; Underwood, M. Can We Identify How Programmes Aimed at Promoting Self-Management in Musculoskeletal Pain Work and Who Benefits? A Systematic Review of Sub-Group Analysis within Rcts. Eur. J. Pain 2011, 15, 775.e1-775.e11.

117. Kores, R.C.; Murphy, W.D.; Rosenthal, T.L.; Elias, D.B.; North, W.C. Predicting Outcome of Chronic Pain Treatment Via a Modified Self-Efficacy Scale. Behav. Res. Ther. 1990, 28, 165-169. [CrossRef]

(C) 2019 by the authors. Licensee MDPI, Basel, Switzerland. This article is an open access article distributed under the terms and conditions of the Creative Commons Attribution (CC BY) license (http://creativecommons.org/licenses/by/4.0/). 